\title{
The Formation and Development of the Dipamkara Prophecy Story:
} The Ārya-Dipamkaravyākarana-nāma-mahāyānasūtra and Its Relation to Other Versions

\section{Matsumura Junko}

\section{Introduction}

In the mdo section of the Tibetan Kanjur, there is an independent sūtra on the Buddha Dīpamkara's Prophecy to the Bodhisattva, i.e. the previous incarnation of the Buddha Śākyamuni. This text, named the Ärya-Dīpamkaravyākarana-nāma-mahāyānasütra (Abb. DVS), was first translated into French by Léon Feer; in Japan, Shizutani Masao 静谷正雄 drew attention to this text, giving a brief outline of it in Japanese. ${ }^{1)}$ The present author published a new translation in English and a comparative study of the episode of the Buddha Dipamkara's birth and his conversion of the people of the capital city of Jambudvipa, Padma (-ka) ${ }^{2)}$ Following up on that previous work, in this paper, the author aims at a further comparison of DVS and other versions of the main episode, in which it is related how the Bodhisattva received the Prophecy that he would become the Buddha Sākyamuni. Following from the influence of the well-known version in Pāli, the Sumedhakatha $\bar{a}$, and from the many sculptural representations found in Gandhāra, there is a prevailing belief that the Bodhisattva spread his hair at the Buddha Dipamkara's feet to prevent them from being muddied; but in many versions, especially in DVS, which is one of the most developed and latest versions, there is no mention of the mud, and therefore it can be seen that it is not an indispensable motif in the story. Rather, the prostrating of himself and spreading his hair on the ground symbolize the Bodhisattva's resolution to become a perfect Buddha in order to save all living beings; this is the moment at which he sets out on the way to the perfection of the Bodhistattva practices.

\section{Texts compared}

(Numbers 1, 2 and 3 refer to story types: Type 1, in which the Bodhisattva's name is not mentioned [he is just "a young Brahman," 需童 or 摩納]; Type 2, in which the Bodhisattva's name is Megha; and Type 3, in which the Bodhisattva's name is Sumati.) ${ }^{3)}$ 
1a) The Xiuxing benqi jing 修行本起經, T184: 3.461a17-462c09.

1b) The Foshuo Taizi Ruiying benqi jing 佛説太子瑞應本起經, T185: 3.472c18-473b11.

1c) The Yichu Pusa benqi jing 異出菩薩本起經, T188: 3.617b18-617c29.

1d) The Liudu ji jing 六度集經 No. 86 (the Rutong shoujue jing 儒童授決經), T152: 3.47c20-48b24.

2a) The Mahāvastu (abb. Mvu; ed. Senart, 1.193-248).

2b) The Ekottarikāgama (abb. EĀ; the Zengyi ahan jing 増壹阿含經) juan 11, T125: 2.597b15$599 \mathrm{~b} 24$.

2b') EA juan 13; This chapter narrates only the Buddha Dipamkara's biography and is therefore not taken up in this paper.]

2b") EĀ juan 38, T125: 2. 2.758a12-c11.

2c) The Sifenlü 四分律, T1428: 22.782a-785c22.

2d) The Fo benxing ji jing 佛本行集經, T190: 3. 664a12-669a3.

2e) The Da Pusa zang huijing 大菩薩藏經 (= The Pusa zang hui 菩薩藏會 the Bodhisattvapitaka in the Mahāratnakūtasūtra 大寶積經), T310: 11.317a16-319b22.

2e') The Foshuo dasheng pusa zang zhengfa jing 佛説大乘菩薩藏正法經, T316: 11.882b6-884a18.

3a) The Divyāvadāna, ed. Cowell-Neil, 246-254.

3b) The Bodhisattvāvadānakalpalatā by Kșemendra, No. 89 Dharmarucyavadāna, ed. Candra Das and Chandra Vidyābhūṣaṇa, 772-821; Vaidya, II.503-515.

3c） The Guoqu xianzai yinguo jing 過去現在因果經, T189: 3.620c15-623a13.

3d) The Fo benxing jing 佛本行經, T193: 4.91c28-83c7.

\section{Comparison of the main plot elements in DVS with other versions}

Element 1: The Bodhisattva's name is sprin (Megha), and he studied with 500 students under the teacher Rin po che (Ratna).

1a) The name of the teacher is not given. 1b) No mention of the teacher. 1c) No mention of the teacher. 1d) The name of the teacher is not given.

2b）Yeruoda 耶若達（ ${ }^{*}$ Yajñadatta） 2c) Zhenbao 珍寶（ ${ }^{*}$ Ratna） 2d）Zhenbao 珍寶（ （彼國雪山南面有一梵志, 名曰珍寶） 2e）Zhenbao 珍罆（ ${ }^{*}$ Ratna）（住大雪山王側, 五百儒童 以爲弟子） 2e'） Miaobao 妙寶 ( ${ }^{*}$ Ratna)

3a) The name of the teacher is not given. 3b) No mention of the teacher. 3c) The Bodhisattva himself is the teacher. 3d) No mention of the teacher.

Element 2: After the Bodhisattva Megha completes his study, he leaves his teacher and goes down from the Himālayas to see the world.

Narration of this plot element is basically the same in all versions.

Element 3: Megha comes to a place where a rich Brahman, sa ga bzang po ( ${ }^{*}$ Višākhabhadra), is sponsoring a big Brahman ritual, in which the winner of the debate is to be given the foremost seat and plenty of gifts; one of the gifts is 500 gold coins and his 


\section{daughter.}

This plot element is only found in $\mathbf{1 a}, \mathbf{2 b}, \mathbf{2 c}$ and $\mathbf{2 d}$; The Brahman's names in each text are:

1a) Buloutuo 不樓陀. ${ }^{4)}$

2b) Name not given. However, he is identified with Daṇạāani in Buddha Sākyamuni’s time (599b24).

2c) Two words appear in the text: Sishi 祀施 and Yeruoda 耶若達 ( ${ }^{*}$ Yajñadatta). 2d) Jiside 祭祀 徳 ( ${ }^{*}$ Yajñadatta, identified with Tantuoboni 檀陀波尼 (Daṇdapānii); 665b21).

In $\mathbf{3 a}$ and $\mathbf{3 b}$, the sponsor of the ritual is King Vāsava. In $\mathbf{1 b}$ and $\mathbf{1 d}$ the Bodhisattva merely comes to a place where 500 Brahmans are holding a debate; there is no sponsor.

Element 4: The daughter of the Brahman, bzang len ldan ( ${ }^{*}$ Bhadravatī), sees Megha and wants to marry him.

In each text she is spoken of as follows:

1a) Xianyi 賢意 ( ${ }^{*}$ Sumati, *Bhadramati).

2b) "a beautiful maiden" (好女一人; it is not known whether she is the daughter of the Brahman sponsor). 2c) Suluopoti 蘇羅婆提 ( ${ }^{*}$ Sauravatî?)。 2d) Shanji 善技 (v.r. Shanzhi 善枝)（665c3）.

3a) The name of the maiden is not given. She is not identified as the daughter of the king. She goes to Dipavatī, the capital city of King Dipa, following the Bodhisattva Sumati.

Element 5: The Bodhisattva Megha shows his knowledge to be superior to that of the so-far foremost old Brahman, dum bu byin ( ${ }^{*}$ Khaṇdadatta), and drives him from the foremost seat to sit there instead himself. The Brahman, dum bu byin ( ${ }^{*}$ Khandadatta) curses him. He is the previous incarnation of Devadatta.

This plot element appears, outside DVS, only in $\mathbf{2 b}, \mathbf{2 c}$, and $\mathbf{2 d}$, although the name of the old Brahman is not given.

Element 6: Megha searches for flowers to offer to the Buddha Dīpamkara. * Bhadravatī, the daughter of the Brahman *Višākhabhadra, who obtains seven lotus flowers from a garland-maker, sells five lotuses to Megha, and entrusts him with the last two flowers to offer to the Buddha Dipamkara in her name.

1a) The name of the girl who sells the flowers is not given. The Bodhisattva buys five flowers and the girl entrusts him with the other two flowers. 1b) She is Gopi (Quyi 賠夷), a servant of the royal house. The Bodhisattva buys five utpala flowers and the girl entrusts him with the other two flowers. 1c) She is Gopi (Juyi 俱夷), a woman who delivers flowers to the royal house. She is carrying seven utpala flowers to the palace. The Bodhisattva sees this and asks her to sell five of them for 500 coins. She asks the Bodhisattva why he would pay all that money for such cheap flowers, and, having heard 
his resolution to become a Buddha, she makes him to promise to take her as his wife in his future lives, and then entrusts him with the other two flowers. 1d) She is Gopi (Juyi 俱夷), the woman who was to be given as a present to the winner of the debate (see Element 3 ). She has followed the Bodhisattva, and been employed by King * Jaya (Zhisheng 制勝) as a flower servant. The Bodhisattva buys five flowers from her.

2a) Megha buys five utpala flowers for 500 purānas from a Brahman girl, Prakrti. ${ }^{5)}$ Prakriti herself offers two utpala flowers to the Buddha Dipamkara. 2b) Megha buys five flowers from a Brahman girl, Shanwei 善味 ( ${ }^{*}$ Surasā?) 。 2c) Megha buys five flowers from Suluopoti 蘇羅婆提 ( ${ }^{*}$ Sauravatî?), the Brahman Viśākhadatta's daughter, who brings 7 lotus flowers from her father's garden. She entrusts the other two flowers to Megha, also to offer to the Buddha Dipamkara. 2d) A watercarrying slave girl called Xianzhe 賢者 ( ${ }^{*}$ Bhadrā or ${ }^{*}$ Mati?) secretly obtains seven flowers from a garland-maker and sells five of them to Megha, and entrusts the last two to him to offer to Buddha Dipamkara in her name. 2e) A woman (no name) has seven utpala flowers. Megha buys five of them (319a16) for 500 kärșāpana; how he obtained the money is not explained. 2e') A girl (no name) has seven utpala flowers. Megha buys (five of) them for 500 gold coins, which he has to give to his teacher as tuition reward. (How he obtained the money is not explained).

3a) The girl who was to be presented to the winner of the debate (no name) afterwards secretly follows the Bodhisattva Sumati. She obtains seven utpala flowers from a garland-maker. She sells five of them to Sumati and offers the last two to the Buddha Dipamkara herself. 3b) King Vāsava's daughter, Sundarī, following the Bodhisattva, goes to Dipavatī; she obtains seven kamala (red lotus) flowers from a garland-maker, sells five of them to Sumati, and offers two flowers herself. 3c) A female servant of the royal house (no name) secretly carries seven blue lotus flowers out of the palace. The Bodhisattva Sumati finds them and asks her to sell five of them. She also entrusts him with the last two flowers to offer to the Buddha Dipamkara. 3d) A woman (no name) has seven blue lotuses. The Bodhisattva Sumati buys five of them, and the last two are entrusted to him by her to offer to the Buddha Dipamkara.

Element 7: Description of lotus flowers strewn over the Buddha Dipamkara: A lofty building made of blue lotus flowers, with four pillars at the four corners, takes shape in the air above the head of the Tathāgata; it is perfectly proportioned, extremely well-established and beautiful; in this lofty building the Tathāgata's body (or "image") also appears.

1a) When the five flowers are strewn, they stay in the air and change into a flower-parasol, covering 70 lis in area; the other two flowers stand on the Buddha's shoulders as if they have roots. 1b) All the flowers that the king and others shower upon the Buddha fall to the ground, but the five flowers that the Bodhisattva throws stay in the air upright as if they have taken root on the Buddha. The two flowers thrown later stay on either side of the Buddha Dipamkara. 1c) When the Bodhisattva casts his flowers over the Buddha's head, the flowers stay there, with their blossoms pointing upwards, as if they have taken root. When the Bodhisattva throws Gopì's flowers, they likewise come to rest upright, 
one on each of the Buddha's shoulders. 1d) When the flowers are showered over the Buddha, they stay there, as if they have been planted by their roots in the ground (by hand).

2a) The five flowers that the Bodhisattva Megha throws stay in the air surrounding the Buddha's face. The two flowers which Prakrti throws also stay in the air. 2b) The Bodhisattva Megha scatters the five flowers and makes a vow (to become a Buddha); there is no description about what happens to the flowers. 2c) When the Bodhisattva Megha throws the seven flowers over the Buddha Dipamkara, the power of the Buddha makes them stay in the air and change into a great flower-parasol of 12 yojanas in width, stalks upwards, and petals downwards. 2d) All the flowers the King and his retinue scatter stay in the air and change into a big parasol made of jewels (compare $\mathbf{1 b}$ and $\mathbf{3 c}$ ). The Bodhisattva Megha also throws the seven flowers with a vow expressing the wish to become a Buddha like the Buddha Dipamkara. These seven flowers stay in the air, petals downwards, and stalks upwards, and make a flower-parasol that follows the Buddha when he moves. 2e) The flowers that the Bodhisattva Megha throws make a row in the air, and then change into innumerable thousands of utpala flowers, all of which, hanging downwards, made a flower-parasol that follows the Buddha as he moves.

$\left.2 \mathrm{e}^{\prime}\right)$ The five utpala flowers, by the supernatural power of the Buddha, change into innumerable $u t$ pala flowers. Diffusing a sweet-smelling fragrance in all directions, they turn into a flower-parasol.

3a) The five flowers that the Bodhisattva Sumati scatters became a big parasol the size of a wheel. The two flowers which the girl throws also change into (two) parasols the size of a wheel and stay near the ears of the Buddha Dipamkara. 3b) The Bodhisattva Sumati prostrates himself at the Buddha Dīpamkara's feet, holding kamala flowers in his hands, and he spreads his hair on the ground. His lotus flowers (padmāni), at that moment, form a vast parasol. The two flowers that Sundari throws over the Buddha become a pair of ear ornaments made of big lotuses. 3c) All the flowers that the king and ministers toss fall to the earth [compare $\mathbf{1 b}$ and $\mathbf{2 d}$ ]. At that time the Bodhisattva Sumati and his 500 disciples cast five flowers, all of which stay in the air and become a flower-parasol. The other two flowers thrown later also stay in the air, standing like attendants on both sides of the Buddha Dipamkara. 3d) The scattered flowers stay in the air, became a blue-lotus-parasol and move following the Buddha Dipamkara. Except for 1a, which is, as seen above, close to versions, 2b, 2c, 2d and DVS, in Type 1 stories, the flowers cast over the Buddha Dipamkara stay in the air, with their blossoms upwards and stalks downwards. In Gandhāran reliefs we can find this type of pictorial representation.

Element 8: In DVS there is no mention made of the mud or mire over which the Bodhisattva is generally considered to have spread his hair so as not to allow the Buddha Dipamkara's feet to get soiled.

1a) The Buddha Dipamkara knows that the Bodhisattva cannot approach him because of a big crowd of people, so he changes a part of the ground into a mire so that the people will be divided on two sides to avoid the mire, and accordingly to make way for the Bodhisattva to approach the Buddha. 1b) There is a brief mention of the mud, but no explanation about where or how it appears. $(=\mathbf{2 b})$. 1c) No mention of the mud. 1d) The Bodhisattva tries to repair the muddy road. This plot element is same as in the Pāli Sumedhakathā. 
2a) No mention of the mud. 2b) There is a brief mention of the mud, but no explanation of where or how it appears. $(=\mathbf{1 b})$. 2b") No mention of the mud. 2c) When people spread costly cloths on the road, the Bodhisattva Megha also takes off his deer-skin garment and spreads it on the road. But the people of the city find it so dirty that they take it and throw it away. The Buddha Dipamkara, knowing the Bodhisattva's intention, changes a part of the earth into a mire in order that Megha can cover it with his deer-skin. 2d) After the flower-offering, the Buddha Dipamkara changes part of the ground to mud. 2e) When people spread costly cloths on the road, the Bodhisattva Megha also takes off his deer-skin garment and spreads it on the road. But the people of the city find it so dirty that they take it and throw it away, and reproach the Bodhisattva. Then the Bodhisattva goes to a muddy place near the crossroads and wishes that the Buddha will see him with his supernatural eye and knowledge, and come and step on his deer-skin garment. The Buddha reads his mind and does so. [The flower-offering comes after this plot element.] 2e') No mention of the mud: When people spread costly cloths on the road, the Bodhisattva also spreads his deer-skin garment. When people reproach him for this, the garment suddenly changes into a cloth made of seven kinds of jewels (883b11-15).

3a) When the Buddha Dipamkara realises that the Bodhisattva and the girl cannot come near him, he causes a big storm and makes a mire. 3b) No mention of the mud. Sumati can come near the Buddha Dipamkara because of his supernatural power. 3c) When the Buddha Dipamkara sees that the Bodhisattva wears a topknot even after he has received the Prophecy, he creates a mire there. The Bodhisattva spreads his deer-skin garment and his hair over the mire to prevent the Buddha's feet from getting soiled: [This is a trick that the Buddha uses to make the Bodhisattva undo his hair-knot, which is a sign of a Brahman-ascetic.] 3d) No mention of the mud.

Element 9: When the Brahman Youth Megha sees this, he is glad, satisfied and happy; it causes him pleasure; and he spreads out his [deer-] skin [on the ground]. Then the people of the royal palace of the capital city, Padmaka, grasp the deer-skin, and throw it back and forth to each other, saying, "Brahman Youth! Are you not crazy? You put your dirty deer-skin where the royal garment was put." Then, the Brahman Youth, Megha, takes up the skin, steps aside from the road, sits down at the side of the road and makes a truth act (satyavacana), saying, "This is my true word: If this Tathāgata is all-knowing, all-seeing, and compassionate to the world, he will step aside and put his feet on my hair."

1a) After the flower-offering, the Bodhisattva rejoices so much that he spreads his hair on the ground and wishes that the Buddha will walk on it. [Note: the hair was not spread on the mud mentioned prior to this.] 1b) After receiving the Prophecy, the Bodhisattva springs high into the sky, and, when he descends to the ground, he sees muddy soil; he spreads his deer-skin garment and his hair to cover it and wishes for the Buddha to tread on his hair. 1c) When the Bodhisattva hears the words of the Buddha Dipamkara's Prophecy, he rejoices greatly and immediately spreads his hair at the Buddha's feet to make him to tread on it. 1d) The Bodhisattva is so overjoyed that he springs seven feet off the ground, and then he descends and spreads his hair on the ground to make the Buddha Dipamkara 
tread on it.

2a) After he offers his flowers, he throws his water-jar away, and prostrates himself at the Buddha's feet. Wiping the Buddha's feet with his hair, he makes a wish to become a Buddha like the Buddha Dipamkara. [This plot element is completely unique; it has so far been found only in Mvu.] $2 \mathbf{b}$ ) After the Bodhisattva offers the flowers, he then spreads his hair on the mud and wishes for the Buddha to walk on it to show his mind and give him a Prophecy. 2b") When the Brahman Youth (= the Bodhisattva) sees the light that the Buddha Dipamkara emits from his mouth re-entering the Buddha's body from the top of his head, he is so overjoyed that he spreads his hair on the ground and says: "If the Buddha does not give me the Prophecy, I will give up my life on this very spot, so that all my

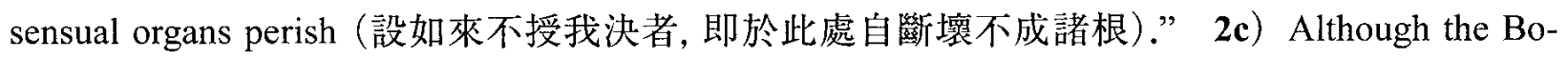
dhisattva Megha tries to cover the mud with his deer-skin garment, it is not big enough. He has a hairtopknot which has not been undone for 500 hundred years. He asks the Buddha if the Buddha will walk on his hair, and when he receives his consent, he undoes his topknot and spreads it on the mud, uttering the following vow: "If the Buddha Dipamkara does not now give me a Prophecy, I will not stand up from this place until my life ends and my form vanishes away." 2d) When people move aside to avoid the mud (that the Buddha Dipamkara has created), the Bodhisattva wishes for his body to become a big bridge (大橋梁; in the Pāli Sumedhakathā, Sumedha also wanted to make his body a bridge, setu), on which the Buddha Dipamkara proceeds without treading in the mud. Then, spreading his deer-skin garment on it, and further undoing his matted hair and spreading it on the garment, he makes a vow that he will in the future become a Buddha equal to the Buddha Dipamkara. 2e) When the Bodhisattva Megha sees the miracle that occurs after the flower-offering, he rejoices all the more, and he unplaits his golden matted hair, which has not been undone for 12 years, and, spreading it on the ground, he makes a vow to attain the highest Enlightenment. The Buddha Dipamkara puts his feet on the hair and gives him the Prophecy. 2e') Megha has practiced asceticism for 12 years with a pure mind, and because of his earnest exertions, he has obtained golden hair. Then he says: "I only wish that the Bhagavan will show sympathy with me; will strengthen me; and will give me a Prophecy that I will quickly attain the highest Enlightenment" (883b24-27).

3a) The Bodhisattva Sumati spreads his hair on the mud that the Buddha Dīpamkara has made by the storm he has conjured up, and says to the Buddha: "If my vow to become a Buddha will be fulfilled, I wish you to tread my hair." 3b) When the Bodhisattva Sumati spreads his hair on the ground, prostrating himself before the Buddha, the Buddha treads on it. Then, when he springs up into the sky and venerates the Buddha, the Buddha Dipamkara gives the Prophecy that he will become a Buddha named Sákyamuni. 3c) When the Bodhisattva Sumati spreads his hair on the mud, the Buddha Dipamkara treads on it and further prophesies that when the Bodhisattva Sumati becomes a Buddha, he will be able to save people as easily as the Buddha Dipamkara. When Sumati hears these words, he is extremely glad, and obtains the recognition that all phenomena do not arise (得無生忍, 622b29), and springs up into the sky to the height of seven tâla trees. After he praises the Buddha in the air and descends, he prostrates himself before the Buddha and asks for permission to become a 
monk. When the Buddha agrees, his hair falls out of its own accord; he is clad in yellow robes and becomes a monk. 3d) After the Bodhisattva sees the miracle after the flower-offering, he prostrates himself before the Buddha, and, spreading his loosened hair on the ground, he wishes for the Buddha to tread on it. Then, having received the Prophecy, he springs up into the air, and again having descended, he prostrates himself at the feet of the Buddha. At that time his hair falls out and stays on the ground. People compete to get his hair, and all who get his hair become monks and attain Arhantship. [A similar plot element is found in $\mathbf{3 a}$ and $\mathbf{3 c}$.]

Element 10: The consort of Śākyamuni: The Śākyan girl * Gopā (literally 'female ruler of the earth,' a kșatriya woman) was at that point in time the Brahman's daughter named Bhadravatī (shākya'i bu mo sa 'tsho ma de'i tshe de'i dus na bu mo bzang len ldan zhes bya bar gyur to.) Her name varies in the different versions as follows:

1a) Gopī (Qiuyi 表夷, the daughter of the king of a small kingdom, Xubofo 須波佛/Shanjue 善覺 Subhadra)

1b) Gopì (Quyi 賠夷)

1c) Gopì (Juyi 俱夷, 619a16)

1d) Gopī (Juyi 俱夷)

2a) Yaśodharā 2b) Gopī (Quyi 賠夷) 2b”) No mention. 2c) Gopī (Śākyan girl, Quyi 釋女, 䨉夷） 2d）Yaśodharā (Yeshutuoluo 耶輸陀羅） 2e) No mention。 2e') No mention. ${ }^{6}$ )

3a) Yaśodharā 3b) Yaśodharā (v. 119) 3c) Yaśodharā (Yeshutuoluo 耶輸陀羅) 3d) ${ }^{*} \mathrm{Mrgā} /$ Mrgī? (Daṇ̣apāṇi-Śākya’s daughter, the Śākyan girl named 'Deer' 執杖釋種女, 釋種女名鹿).

\section{Conclusion}

Although many articles have been published on the Dipamkara Prophecy story, they have not succeeded in giving a complete schematic overview of the story as told in all the various versions and in describing their historical development, because none of them have systematically compared all versions. ${ }^{7)}$ However, from the comparison of all the Northern versions enumerated above and DVS in the Tibetan Kanjur, the following conclusions can be drawn:

1) The woman who sells flowers (usually five blue lotus flowers, utpala) to the Bodhisattva makes him to promise to make her his wife until he attains Perfect Enlightenment. She is identified with Śākyamuni's wife.

2) The Bodhisattva's hair-spreading cannot be regarded as an act of veneration ( $p \bar{u} j \bar{a})$ in the strict sense of the word, although the term fuhatsukuyo 布髪供養 ('hair-offering') is often used in articles by Japanese scholars; rather, it shows his resolution to become a Buddha and his firm determination not to stand up until his vow is confirmed by the Buddha Dipamkara stepping on his hair. Further, it is not always to cover the muddy soil. There are many versions in which there is no mention of the mud, including DVS, which is 
one of the latest versions.

3) The name of Śākyamuni’s wife is Gopī or Yaśodharā (Pāli: Yasodharā). In Type 1 versions, her name is always Gopí; in Type 2 versions, her name is mainly Gopi, but there are also Yaśodharā versions; and in Type 3 versions, her name is always Yaśodharā.

4) As seen above, plot elements 3-5, which explain how the Bodhisattva obtained 500 gold coins to buy the five lotus flowers, and also state that the young woman who sold the lotus flowers and asked the Bodhisattva to promise to make her his wife in his later births was of noble birth and a daughter of a rich Brahman, are seen only in a limited number of versions. Obviously these plot elements were innovations late in the development of the story. This plot element alone also shows that DVS has a very close relationship with 1a, $\mathbf{2 b}, \mathbf{2 c}$ and $\mathbf{2 d}$. $^{8}$ )

This point is also important in showing how the understanding of Śăkyamuni's marriage and his consort's conception of Rāhula changed in Northern Buddhism, especially in Mahāyāna Buddhism. In brief, in contrast to the Theravāda tradition, the purity or celibacy of Säkyamuni gradually became regarded as more important. Accordingly, the status of Yaśodharā, Rāhula's mother, diminished, and, instead, Gopī, who might be a fictitious woman, was placed in the first rank among queen-consorts. (In later traditions, Śākyamuni had two or three wives, and in such traditions, Gopī/Gopā was always a principal queen.) Gopì is a very common name in Indian culture, meaning 'cow-herd girl,' which is not appropriate for the name of the Buddha's wife; later, her name was changed to Gopā, 'the protector of the dharma,' deriving from the verb gup- 'to protect,' and she is also said to have belonged to the Sākya clan.

From the examination of the Dippamkara Prophecy story, we can see how a simple, old story evolves through the gradual addition of other or more detailed plot elements, and subplots that explain the causes or reasons for other plot elements. This study shows the importance of more attention to and further elucidation of the way Buddhist narratives were adopted and incorporated in early Mahāyāna Buddhist texts, as shown in the examples found in the Bodhisattvapitakasūtra and the Gandavy $\bar{u} h a$. In the same way, in many other Mahāyāna Buddhist sūtras, narratives originating in the earlier Buddhist texts are often used to provide the framework or setting for newly propagated Mahāyāna sūtras, or to expound a new interpretation of the Buddha's image of those texts, and to emphasize Mahāyānistic Bodhisattva ideals. 
1 ) Shizutani Masao (1975). "Chibetto yaku Shō Nentōjuki Daijōkyō ni tsuite," Journal of the Indian and Buddhist Studies, 24-1, 233-236. For information about this article the author is indebted to Dr Amano Makoto, and expresses her sincere gratitude to him.

2) Matsumura Junko (2011.10), "An Independent Sūtra on the Dīpamkara Prophecy: Tibetan Text and English Translation of the ĀryaDīpaṃkara-vyākaraṇa nāma Mahāyānasūtra," (Journal of the International College for Postgraduate Buddhist Studies) Vol.15, 81-141. For a detailed bibliography, refer to this article. See alco; Taddei, Maurizio (2003). "The Dīpamkara-Jātaka and Siddhārtha's Meeting with Rāhula: How are they linked to the flaming Buddha?" On Gandhära, Collected Articles (Nopoli 2003), 329-334.

For these three types see Matsumura Junko (2011.3), "The Story of the Dipamkara Buddha Prophecy in Northern Buddhist Texts: An Attempt at Classification," Journal of Indian and Buddhist Studies, 59-3, 1137-1146. 4) The author cannot give any suggestion about the equivalent Skt word for this transcription. 樓陀 in 不樓陀 may correspond to Skt rudra- or rudda-: 樓陀天 (the God Rudra) in the Dabanniepan jing 大般涅槃經 T374: $12.508 \mathrm{~b} 2$. 5 ) purāna also means a gold coin. MW s.v. purānaka- 'purāna,' a partic. coin.' Cf. Sten Konow, "Mathura Brahmi Inscription of the Year 28," Epigraphia Indica, vol.XXI (1931-32), pp.55-61 (Especially p.58 and p.61), according to which coins called purānas were used in Northern India in the Kusāna period. The more commonly used word for a gold coin in the Indian subcontinent is kārśāpana as, for example, used in Div.

6) The following passage in the three translations of a sūtra in the Ratnakūta is of interest: 唯夷本 於然燈佛時, 作如是言: 從今已後願爲此梵志, 乃至一生補處, 常爲我夫, 我爲其妻. 爾時菩薩, 即受七枝優鉢羅花已, 作如是言, 我雖不受, 今當滿此善女人願, 作是願已. 不離七花善根, 是故 菩薩納以舀妃 (The Da baoji jing 大寶積經 The Dasheng fangbian hui 大乘方便會 in the Da baoji jing 大寶積經, translated by Zhu Nanti 丛難提 (Nandin) in the early 5th century CE; T310: 11.601b1217); 欲除沈吟故納賟夷釋氏之女, 縁此現生子男羅云. 假論羅云胞胎生者則非義也. 所以者何, 羅云於天變沒化生, 不由父母合會而育. 又是菩薩本願所致. 昔錠光佛瞧夷有誓, 後世爲仁妻殖其 徳本, 不違久要故娉納之（The Huishang pusa wen dashanquan jing 慧上菩薩問大善權經 translated by Zhu Fahu 竺法護 (Dharmarakșa, 3-4th Century CE: T345: 12.161b16-21,); 菩薩納耶輸陀羅而 爲妻者, 菩薩爲欲令耶輸陀羅滿宿願故. 彼耶輸陀羅, 往昔曾於燃燈佛所, 發是願言, 願我當於 釋迦育尼佛法中爲釋種女種諸善根. 以彼宿世無虚妄言, 是故我今納以爲妻 (The Foshuo dafangguang shanqiao fangbian jing 佛説大方廣善巧方便經 translated by Shihu 施護 (Dānapāla, 11th Century CE): T346: 12.173a22-27). 7 ) Numerous brief mentions of the Dipamkara Prophecy found in many Buddhist scriptures are also excluded from this study, as they are useless for comparison. 8 ) For other evidence which shows the close relationship of DVS with $\mathbf{1 a}, \mathbf{2 b}, \mathbf{2 c}$ and $\mathbf{2 d}$, see Matsumura 2011.10.

(The research for this article was supported by the Grant-in-Aid for Scientific Research (B) No. 21320015 from JSPS)

〈Key words〉 Árya-Dīpamkaravyākarana-nāma-mahāyānāāutra, 佛本行集經, Megha, Sumati, Gopī (Professor, International College for Postgraduate Buddhist Studies, Ph.D.) 